\title{
Determinants of Foreign Direct Investment in China's Real Estate Market
}

\author{
Jing Cao \\ School of Economy \& Management \\ Nanjing University of Science \& Technology \\ Nanjing, China
}

\author{
Yongjian Zong \\ School of Economic \& Management \\ Nanjing University of Science \& Technology \\ Nanjing, China
}

\begin{abstract}
Since 2000, foreign direct investment in China's real estate industry has been increasing year by year. Based on the theory of direct investment in the service industry and previous research and analysis, this paper conducts a quantitative study on determinants affecting foreign direct investment in China's real estate market, including: market size, exchange rate, market openness, labor cost, land cost, financing cost, etc. Based on the empirical analysis, this paper draws conclusions and gives some policy recommendations: first, the development of various regions in China is different, and effective policies should be taken to attract FDI in the real estate market according to local conditions; second, the government should create a fair and reasonable competition environment.
\end{abstract}

Keywords-real estate; foreign direct investment; determinants

\section{INTRODUCTION}

Since the beginning of the 21 st century, with the deepening development of globalization, most countries have gradually implemented liberalization policies, and restrictions on foreign direct investment (FDI) in the service industry have been decreasing. Although the outbreak of the global financial crisis, the scale of FDI in the service sector has been high, in many service sectors, the real estate industry is also undergoing changes towards a more international direction.

Following the trend of FDI worldwide, FDI in China is gradually inflowing into the service sector. In the mid-1990s, FDI in the real estate market accounted for $9-16 \%$ of the total FDI in China. However, since 2006, FDI in China's real estate market has exploded, accounting for about 20 percent of the total FDI in China. In 2014, the FDI in China's real estate market was 34.62 billion us dollars, reaching a historical high, accounting for $28.96 \%$ of total FDI in China that year. It did not decline until 2016. In 2016, the total amount of FDI into the real estate industry was 19.66 billion us dollars, accounting for $15.6 \%$ of the total amount of foreign direct investment actually used.

A large amount of foreign investment in China has aroused wide attention of scholars and a lot of research has been done. Previous studies have mainly focused on China's total FDI or manufacturing FDI, and very few studies have studied FDI in the real estate market. Due to lack of studies on FDI in China's real estate market, and the latest study data by the end of 2015, the environment of China's real estate market has undergone great changes, both economically and institutionally. So, in this context, the newest data are made use to makes a quantitative analysis of the factors influencing FDI in China's real estate market, and gives policy recommendations through the analysis results. The second part of this paper is a literature review, the third part is a theoretical analysis of relevant influencing factors, the fourth part is an empirical analysis, and the fifth part is a conclusion and policy recommendations.

\section{LITERATURE REVIEW}

Some existing literature shows that FDI in the real estate industry can help the economic development of host countries, including direct provision of economic resources, additional competition, job creation and technology provision (Golub, 2009).In addition, FDI in the real estate industry has made a significant contribution to the globalization of metropolises and the rapid development of urbanization (Wei et al., 2006). Some scholars believe that the inflow of FDI makes the host country's real estate industry perform well. For example, Fung et al. (2010) discussed that since 1997, domestic and especially foreign investors' investment in China's real estate market has stimulated the demand of electronics, machinery, steel and construction industries

There are also some studies analyzing determinants of FDI in China's real estate market. $\mathrm{He}$ and Zhu (2006) interviewed 12 foreign-funded real estate enterprises in Shanghai in 2002 by using semi-structured questionnaire, found that the major reasons for FDI in Shanghai real estate market is the market potential, location, preferential tax, investment diversification, instant profits, etc. Fu (2009) found that cultural differences constitute a major barrier to foreign investors entering Chinese real estate. He, Wang and Cheng (2009) studied the impact of local market, regional governance and housing reform on FDI in real estate market. Their research results show that foreign investors value the return on capital when choosing the location of investment. He and Zhu (2010) show that FDI in China's real estate market generally falls into large cities with large population, foreign investment and tourists. Guo, Dong (2015) based on 2001-2013 panel data of 26 provinces in China to analyze 
determinants of FDI in China's real estate market. They thought the main factors of attracting FDI in real estate in the eastern region of China and the central and western regions are quite different. In the eastern region, foreign currency income and government intervention are the main factors, while in the central and western regions, infrastructure construction and natural environment are the main factors.

\section{THEORETICAL ANALYSIS}

There is no mature theoretical framework for foreign direct investment in the service industry. Most researches follow the theory of foreign direct investment in manufacturing.

\section{- Monopoly advantage}

The monopoly advantage of service enterprises is the ability of information acquisition and processing. Another monopoly advantage is product standardization, which depends on the brand, management, organization and marketing technology of enterprises.

\section{- Location advantage}

It is mainly reflected in two aspects: first, the supply capacity of the host country, that is, the host country has good infrastructure, excellent human resources; second, the market demand capacity of the host country, that is, the host country itself has a broad market prospect or is closer to the market demand.

\section{- Internalization advantage}

Due to the characteristics of experience and invisibility of service products, the problem of information asymmetry is more prominent than that of many manufactured products. It is also more difficult to protect the intellectual property rights of service products. These factors promote the service industry to adopt more FDI when expanding abroad.

In addition, some scholars believe that service products have different characteristics from manufacturing products, so the theory applicable to manufacturing may not be able to explain the phenomenon and problems of service industry. They hold that the basic characteristics of service products include invisibility, high differentiation of products, and inseparability of production and consumption. These characteristics make the expansion decisions of service enterprises greatly different from that of manufacturing industry, thus hindering the FDI of service industry.

Based on the theory of FDI and the unique characteristics of the real estate industry, this section will specifically analyze the determinants of FDI in China's real estate market.

\section{A. Market Size and Potential}

Multinational corporations pay attention to market size and potential in the process of market expansion. In regions with larger markets, entry costs can be reduced through economies of scale. High market potential means good earnings prospects and capital investment can bring positive returns. In the context of rapid economic growth, China's market scale is also expanding. For foreign businesses,
China's real estate market growth potential is extremely high So, it can be held that: larger market size and higher market potential will attract more FDI flows into China's real estate industry.

\section{B. Transportation Infrastructure}

According to Dunning's theory on service industry expansion, in terms of location advantages, whether the host country has good infrastructure, excellent human resources will affect the inflow of FDI. The development of the real estate is related to the local transportation infrastructure. Convenient transportation areas mean more frequent movement of people, which will bring certain market demand to the local area. Therefore, foreign investors are more inclined to invest in areas with convenient transportation. Here, data of ten provinces for observation are selected, and use the ratio of total highway mileage and railway mileage to provincial area to represent the local infrastructure construction level; the specific data is shown in "Table I".

TABLE I. TRANSPORTATION INFRASTRUCTURE LEVEL AND INFLOW SCALE OF FDI IN REAL ESTATE IN SOME REGIONS OF CHINA IN 2016

\begin{tabular}{|c|c|c|}
\hline Region & $\begin{array}{l}\text { Transportation } \\
\text { Infrastructure } \\
\text { Level }\left(\mathbf{k m} / \mathbf{k m}^{2}\right) \\
\end{array}$ & $\begin{array}{c}\text { Inflow Scale of FDI } \\
\text { in Real Estate(billion } \\
\text { Yuan) }\end{array}$ \\
\hline Beijing & 1.42 & 112.87 \\
\hline Shanghai & 2.17 & 663.58 \\
\hline Guangdong & 1.24 & 1432.06 \\
\hline Jiangsu & 1.49 & 1065.56 \\
\hline Zhejiang & 1.15 & 721.72 \\
\hline Anhui & 1.44 & 166.84 \\
\hline Jiangxi & 0.99 & 54.41 \\
\hline Guizhou & 1.11 & 76.37 \\
\hline Shanxi & 0.78 & 102 \\
\hline Gansu & 0.28 & 3.65 \\
\hline
\end{tabular}

From the data of most provinces, it can be seen that in areas with higher ratio, FDI in the real estate market is larger.

\section{Market Liberalization}

The market liberalization is an important element of a country's market environment. Less government intervention and a higher degree of marketization will inevitably enhance economic vitality and attract foreign investment. However, the real estate industry often affects the stability of a country's economy, and the influx of excessive foreign capital will cause economic instability. Therefore, many countries have clear restrictions on foreign capital entering the real estate industry. However, with the accession of more and more countries to the WTO, most countries gradually allow FDI in the real estate industry. Since 2001, China has accelerated the marketization process, but the degree of marketization still varies greatly among different regions. The proportion of total imports and exports in regional GDP can be used to reflect the openness of a region. 
TABLE II. THE AMOUNT OF FOREIGN-FUNDED REAL ESTATE ENTERPRISES AND THE PROPORTION OF TOTAL IMPORT AND EXPORT IN REGIONAL GDP IN SOME REGIONS OF CHINA IN 2016

\begin{tabular}{|c|c|c|}
\hline Region & $\begin{array}{c}\text { the Amount of } \\
\text { Foreign-funded Real } \\
\text { Estate Enterprises }\end{array}$ & $\begin{array}{c}\text { The Proportion of } \\
\text { Total Import and } \\
\text { Export in Regional } \\
\text { GDP (\%) }\end{array}$ \\
\hline Beijing & 223 & 74.90 \\
\hline Shanghai & 396 & 104.36 \\
\hline Guangdong & 866 & 79.36 \\
\hline Jiangsu & 573 & 44.18 \\
\hline Zhejiang & 339 & 47.77 \\
\hline Anhui & 80 & 12.17 \\
\hline Jiangxi & 83 & 14.37 \\
\hline Guizhou & 41 & 3.20 \\
\hline Shanxi & 42 & 10.31 \\
\hline Gansu & 15 & 6.29 \\
\hline
\end{tabular}

"Table II" lists the amount of foreign-funded real estate enterprises in ten provinces and the proportion of total import and export in GDP of each province in 2016. From the data of most provinces, it can be concluded that higher degree of market openness will attract more FDI in the real estate.

\section{Cost}

Cost is an important factor that corporations must consider. Due to the particularity of the real estate, the cost is mainly considered in three aspects: labor cost, land cost and financing cost.

In many previous literatures, when analyzing the influencing factors of FDI in the service industry, it may be that labor cost is not taken as an important factor because capital cost is more important and most FDI in the service industry is market-oriented. However, labor cost is an important cost of real estate corporations.

Secondly, the cost of land is the biggest cost of real estate corporations, which is a unique feature of the real estate. Higher land cost will increase the burden of real estate enterprises.

Finally, real estate enterprises generally have very high leverage, which means that the financing cost has a great impact on the decision-making, so the financing cost will become a factor affecting FDI in the real estate. Rodr guez (2010) empirically analyzed the determinants of FDI in Spain's real estate market, which was found to be negatively correlated with long-term interest rates. That means foreign investors prefer regions that can borrow easily from commercial banks.

Based on the above analysis, it can be concluded that: labor cost, land cost and financing cost would affect foreign investors' decision, and regions with lower cost are more likely to attract FDI into the real estate industry.

\section{EMPIRICAL ANALYSIS}

\section{A. Selection of Variables and Data Sources}

According to the theoretical analysis in the third part, this paper selects the corresponding variables from the aspects of market size and potential, transportation infrastructure, market openness and cost.

This article selects regional GDP and sale price of house per unit to measure market size and market potential. Regional GDP reflects the level of local development, and the sale price can reflect potential profit.

Foreign investment in real estate is more inclined to choose places with convenient transportation and low transportation cost for investment, that is, regions with good infrastructure construction are more likely to attract foreign investment. This paper chooses the ratio of road mileage to provincial area within the region to represent the level of local infrastructure construction.

Market liberalization is an important factor. A region of the greater the degree of opening to the outside world, which indicates that the restrictions on foreign investment in this area is less, the optimal benefit is more, the region will attract more foreign capital. This paper uses the proportion of imports and exports in regional GDP and exchange to measure Marketization degree of the province.

Cost includes labor cost, land cost and financing cost. Low cost can improve return on capital, while high profit is the goal pursued by enterprises. The higher the cost, the less likely it is to attract foreign capital, and the higher the profit, the more favorable it is to attract foreign capital. In this paper, wage of the real estate industry per capita is used to represent the labor cost, and the cost of completed housing per unit is used to represent the land cost. The loan amount of real estate enterprises in the region represents the financing cost, and the larger the loan amount is, the easier the financing is, that is, the lower the financing cost.

Due to the lack of statistical data of some provinces, this paper uses the data of 23 provinces in China from 2008 to 2017. The total amount of FDI in real estate was selected as the explained variable, and the data were obtained from China real estate statistical yearbook (2009-2018). The explanatory variable was calculated based on the data of the national bureau of statistics of China (2009-2018). For the purpose of calculation, all foreign currency amounts in this study are converted into Yuan according to the actual exchange rate in the current year. (See "Table III" for details) 
TABLE III.

THE SOURCES OF DATA

\begin{tabular}{|l|l|l|l|}
\hline \multicolumn{1}{|c|}{ Variable } & \multicolumn{1}{|c|}{ Measure } & \multicolumn{1}{c|}{ Unit } & \multicolumn{1}{c|}{$\begin{array}{c}\text { Expected effect on FDI in } \\
\text { real estate }\end{array}$} \\
\hline FDIRE & $\begin{array}{l}\text { Amount of direct investment in real estate from foreign } \\
\text { corporations }\end{array}$ & Billion Yuan & \\
\hline GDP & regional GDP & Billion Yuan & + \\
\hline Price & Sale price of house per unit & Yuan & + \\
\hline Trans & Ratio of road mileage and provincial area & $\mathrm{km} / \mathrm{km}^{2}$ & + \\
\hline Wage & Wage of the real estate industry per capita & Yuan & - \\
\hline Con & Cost of completed housing per unit & Yuan & - \\
\hline Fin & Loan amount of real estate enterprises in the region & Billion Yuan & + \\
\hline Open & Proportion of total imports and exports in regional GDP & percent & + \\
\hline EX & Exchange in current year & & - \\
\hline
\end{tabular}

\section{B. Panel Data Model}

At present, multiple linear regressions is the most widely used method in the research, but this method can easily lead to the occurrence of missing variables. This paper uses panel

$$
\text { FDIRE }_{\text {it }}=\alpha+\beta_{1} \text { GDP }_{\text {it }}+\beta_{2} \text { Price }_{\text {it }}+\beta_{3} \text { Trans }_{\text {it }}+\beta_{4} \text { Wage }_{i t}+\beta_{5} \text { Con }_{\text {it }}+\beta_{6} \text { Fin }_{\text {it }}+\beta_{7} \text { Open }_{\text {it }}+\beta_{8} \text { EX }_{\text {it }}+\varepsilon_{\text {it }^{\prime}}
$$

In the above equation, $\mathrm{i}$ is the individual of the crosssection sample, $\mathrm{t}$ is the time, and random error $\varepsilon_{i t}$ satisfies the assumption that the mean value is zero and $\sigma^{2}$ is equal.

In order to ensure the validity of model estimation, before using panel data regression, it is necessary to first determine whether to use fixed effect model or random effect model. In this paper, Hausman test and F test are adopted to carry out regression by using fixed effect model.

\section{EMPIRICAL RESULTS AND ANALYSIS}

This paper focuses on determinants of foreign direct investment in China's real estate market. On the basis of theoretical analysis and previous research results, this paper conducts empirical test and analysis. The regression results are shown in "Table IV".

The results in the table show that, FDI in China's real estate market tends to inflow into regions with market potential, and regions with large market potential also data regression model, which can effectively control the deviation caused by missing variables.

The general expression is: indicate that the return rate of foreign direct investment is higher. Market liberalization is very attractive to foreign investment, and real estate industry profits rely mainly on location itself, so not familiar with local market will bring high risk of doing business. If the investment is made in regions with high marketization degree and transparent relevant policies and regulations, it will bring certain guarantees to foreign investors and reduce their investment risks. Meanwhile, it can be seen that the cost factor has significantly affected FDI in China's real estate. Real estate investors are more inclined to invest in areas with lower labor cost, land cost and financing cost. Finally, the impact of infrastructure construction is not significant, which may be mainly caused by two reasons: first, the data selection is not comprehensive and reasonable enough to reflect the situation of infrastructure in the region; second, foreign investment in real estate is optimistic about the Chinese market and more concerned about the market potential. Therefore, infrastructure construction is not an important consideration when making investment choices.

TABLE IV. REGRESSION RESULTS

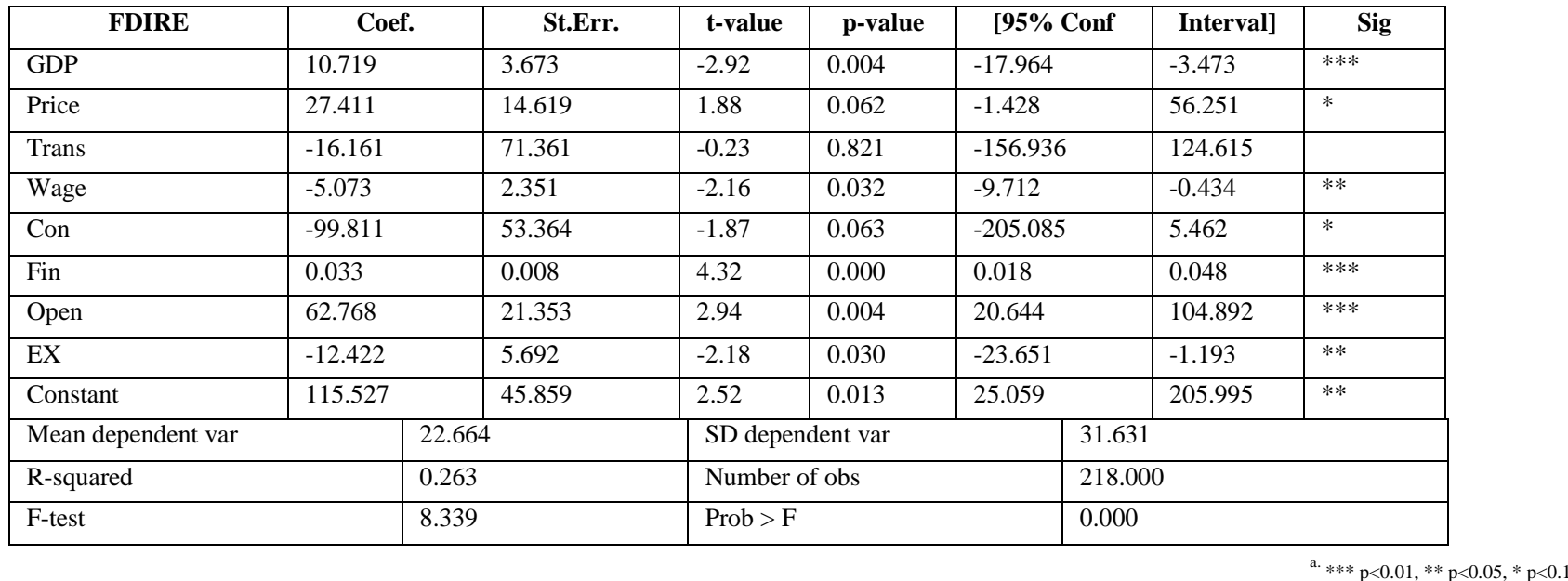




\section{CONCLUSIONS AND RECOMMENDATIONS}

\section{A. Conclusions}

This paper makes a quantitative analysis of the determinants of FDI in China's real estate industry, and mainly comes to the following conclusions:

First, in China, regions with large market potential are easy to attract FDI in the real estate market. Because the large market size often means that there is a large market demand, so for real estate enterprises, there is a good profit prospect.

Second, areas with higher degree of marketization can attract more FDI in the real estate market. The liberalization of the market has great attraction to foreign capital, and the profit mainly depends on the location. Therefore, if the investment is carried out in the region with high marketization degree and transparent relevant policies and regulations, it will bring certain guarantees to foreign investors and reduce their investment risks.

Third, labor cost, land cost and financing cost are the factors that foreign investors must consider when they make investment in China's real estate market. The lower the cost, the higher the return on investment

Fourth, foreign investors show no preference for infrastructure when choosing location in China. Theoretical analysis generally thinks that direct investment tends to choose regions with convenient transportation and good infrastructure. Areas with good infrastructure construction have more convenient transportation and communications, and frequent personnel flow will bring more market demand, thus attracting more foreign investment in real estate. There may be two reasons: first, the selection of regression data in this paper is not comprehensive and reasonable enough to reflect the situation of infrastructure in the region; second, foreign investment in real estate is optimistic about the Chinese market and more concerned about the market potential. Therefore, infrastructure construction is not an important consideration when making investment choices.

\section{B. Recommendations}

According to the analysis results, the following three policy recommendations are proposed:

First, market potential, market openness and cost factors significantly affect FDI in China's real estate market. However, in China, there is a long-term imbalance in the economic development of various regions, so there is a big difference in market potential, demand, cost and other aspects. Therefore, different provinces have different attraction to FDI in the real estate market. Each region shall take corresponding measures in light of its actual situation.

Second, in this paper, although the impact of infrastructure factors is not significant, with the continuous development and maturity of China's real estate market, infrastructure will also be an important factor affecting foreign investment. Therefore, in areas with weak infrastructure, the government should vigorously strengthen the construction of transportation, communications, develop ports, roads, railways and aviation networks, and strengthen its own infrastructure construction.

Third, China's central and local governments face various challenges in conducting foreign investment policies at present, and government should form a fair and reasonable competition environment so that more FDI will inflow.

\section{REFERENCES}

[1] G. L. Guo and J. Dong, "Research on the determinants of foreign direct investment in real estate in China's location selection -- Based on panel data analysis," Future and development, vol.39,No.4, 2015, pp. 41-47.

[2] C. M. Hui, and Ka Kwan Kevin Chan, "Foreign direct investment in China's real estate market," Habitat International, vol.43, 2014, pp.231-239.

[3] C. He, and Y. Zhu, "Real estate FDI in Chinese cities: local market conditions and regional institutions," Eurasian Geography and Economics, vol.51, No.3, 2010, pp.360-384.

[4] C. Rodríguez, and R. Bustillo, "Modeling foreign real estate investment: the Spanish case," Journal of Real Estate Finance and Economics, vol.41, No.3, 2010, pp.354-367.

[5] H. G. Fung, J. L. Jeng, and Q. W. Liu, "Development of China's real estate market," The Chinese Economy, vol.43, No.1, 2010, pp.71-92.

[6] S. S. Golub, "Openness to foreign direct investment in services: an international comparative analysis," The World Economy, vol.32 No.8, 2009, pp.1245-1268.

[7] K. Fu, "Foreign direct investment in the Chinese real estate market with focus on cross-cultural business," Master of Science Thesis, vol.43, No.6, 2009, pp.237-251.

[8] C. He, J. Wang, and S. Cheng, "What attracts foreign direct investment in China's real estate development?" The Annals of Regional Science, vol.46, No.2, 2009, pp.267-293.

[9] J. Zhu, L. Sim, and X. Zhang, "Global real estate investments and local cultural capital in the making of Shanghai's new office locations," Habitat International, vol.30, No.3, 2006, pp.462-481.

[10] Y. D. Wei, C. K. Leung, and J. Luo, "Globalizing Shanghai: foreign investment and urban restructuring," Habitat International, vol.30, No.2, 2006, pp.231-244.

[11] F. Wu, "China's recent urban development in the process of land and housing marketisation and economic globalization," Habitat International, vol.25, No.3, 2001, pp.273-289.

[12] D. Jiang, J. Chen, and D. Isaac, "The effect of foreign investment on the real estate industry in China," Urban Studies, vol.35, No.11, 1998, pp.2101-2110. 